\title{
Fast Decline of Hematopoiesis and Uncoupling Protein 2 Content in Human Liver after Birth: Location of the Protein in Kupffer Cells
}

\author{
PETR BRAUNER, MARYSE NIBBELINK, PAVEL FLACHS, IVANA VÍTKOVÁ, PAVEL KOPECKÝ, \\ IRENA MERTELÍKOVÁ, LENKA JANDEROVÁ, LUC PÉNICAUD, LOUIS CASTEILLA, \\ RICHARD PLAVKA, AND JAN KOPECKÝ \\ Institute of Physiology Center for Integrated Genomics, Academy of Sciences of the Czech Republic, \\ Prague, Czech Republic [P.B., P.F., I.M., J.K.]; Unité Mixte de Recherche 5018 University Paul Sabatier, \\ Centre National de la Rederche Scientifigne, Institut Louis Bugnard, Toulouse, France [M.N., L.P., L.C]; \\ and Pathological Institute [I.V.] and Division of Neonatology, Department of Gynaecology and Obstetrics \\ [P.K., R.P], General Hospital of the $1^{\text {st }}$ Medical Faculty, Charles University, Prague, Czech Republic
}

\section{ABSTRACT}

Hepatic hematopoiesis is prominent during fetal life and ceases around birth. In rodent liver, the decline of the hepatic hematopoiesis starts abruptly at birth being accompanied by a decrease of mitochondrial uncoupling protein 2 (UCP2) expression in monocytes/macrophages, whereas hepatocytes may express UCP2 only under pathologic situations. The goals of this study were to characterize hepatic hematopoiesis in humans around birth, and to identify cells expressing UCP2. Hematopoiesis was evaluated histologically in the liver of 22 newborns (mostly very premature neonates), who died between 45 min and $140 \mathrm{~d}$ after birth, and one fetus. UCP2 expression was characterized by Northern blots, immunoblotting, immunohistochemistry, and by in situ hybridization. The number of hematopoietic cells started to decrease rapidly at birth, irrespectively of the gestational age (23-40 wk) of neonates. A similar decline was observed for UCP2 expression, which was relatively high in fetal liver. UCP2 was detected only in myeloid cells (mainly in Kupffer cells), but not in hepatocytes, although sepsis or other pathologies occurred in the critically ill newborns. Kupffer cells represent the major site of mitochondrial UCP2 expression in the human newborn. UCP2 may be essential for the differentiation and function of macrophages and serve as a marker for these cells in human liver during the perinatal period. (Pediatr Res 49: 440-447, 2001)
Abbreviations
UCP2, uncoupling protein 2
$\operatorname{PPAR} \gamma$, peroxisome proliferator-activated receptor $\gamma$
ROS, reactive oxygen species
SSC, standard saline citrate
BCIP/NBT, 5-bromo-4-chloro-3-indolyl phosphate and nitro
blue tetrazolium

The liver is important for hematopoiesis in human embryonic and fetal life. This organ is colonized by yolk-sac-derived stem cells by $5-6 \mathrm{wk}$ of gestation, and the liver is the primary source of red blood cells from the 9th week on. During the 24th week, bone marrow replaces the liver as the main site of hematopoiesis (1-4). Hematopoietic activity in human liver is thought to cease soon after birth. However, the relative importance of the gestational age of the fetus and the process of birth, respectively, on the postnatal decline of hepatic hematopoiesis is not well defined $(1,5-8)$.

Received May 25, 2000; accepted August 10, 2000.

Correspondence: Jan Kopecký, M.D., Ph.D., Institute of Physiology, Academy of Sciences of the Czech Republic, 14220 Prague, Czech Republic.

This work was supported by the March of Dimes Birth Defects Foundation (grants \# 6-FY98-0349 and 6-FY00-331), the Grant Agency of the Ministry of Health of the Czech Republic (grant \# 4643-3), and two travel grants (NATO \# LST.CLG97502; and Barrande \# 98082-2).
In addition to erythroid differentiation, myelopoiesis, lymphopoiesis, and megakaryocyte production take place in the fetal liver $(2,8)$. The factors, that affect cell lineage preference of hematopoietic stem cells, as well as the interactions between cells of different lineages during their replication and differentiation, are now intensely characterized [for refs., see $(4,9$, 10)]. New cell-type-specific markers to study the development of the hematopoietic system are required. Our recent study (11) has identified mitochondrial UCP2 as a specific marker of monocyte/macrophage cells developing in mouse and rat liver. The liver was the major site of UCP2 expression in the rodent fetus and the level of UCP2 mRNA declined soon after birth. Also in the liver of adult animals, UCP2 was found in monocytes/macrophages and not in hepatocytes (12). However, under pathologic situations, such as during inflammation (13), steatosis $(14,15)$, or neoplastic transformation (16), UCP2 gene expression could occur also in the hepatocytes of adult animals. 
$\mathrm{UCP} 2$ is a relatively new member $(17,18)$ of the family of mitochondrial UCPs (19). It is highly expressed in the spleen and the thymus $(20,21)$, probably reflecting contribution by tissue macrophages $(11,12)$, as well as in peripheral blood leukocytes $(20)$ and in adipose tissue $(17,18)$. This protein may control the efficiency of oxidative phosphorylation, and mitochondrial synthesis of ATP, via its protonophoric shortcircuiting activity in the inner mitochondrial membrane (1719, 22-24). The function of UCP2 is probably tissue-specific. In macrophages, UCP2 may inhibit the production of ROS in mitochondria (21). The present research was designed to characterize hepatic hematopoiesis and UCP2 expression during perinatal development in humans. Very premature neonates, who died at different postnatal age, were mainly studied.

\section{METHODS}

Human material. Liver samples were obtained from 22 human newborns during autopsy 2-3 h after death. Most of the newborns had very low birth weight $(<1000 \mathrm{~g}$ with gestational age at birth between 23 and 32 wk; 16 cases); they died between $45 \mathrm{~min}$ and $140 \mathrm{~d}$ after birth. There were also six children with a birth weight $>1000 \mathrm{~g}$ (and gestational age $>28$ wk); two of theses were full-term neonates (Table 1, cases A0 and A62). Some of the newborns were already enrolled in our previous study (25) (Table 1). Infants born from mothers who suffered from endocrinological disorders or who abused drugs were not eligible for the study. One fetus, which originated from legal termination of pregnancy after $23 \mathrm{wk}$ of gestation because of a hereditary disease, was also included (Table 1). The study protocol conforms to the ethical guidelines of the 1975 Declaration of Helsinki, and it was a priori approved by the Committees of Medical Ethics at all the collaborating institutions. Informed consent was obtained from the parents. Samples were frozen and stored in liquid nitrogen for isolation of total RNA and for immunoblotting analysis. Tissues were also fixed for histopathological and immunohistochemical examinations (see below).

Mouse material. Adult male C57BL/6J mice maintained at $20^{\circ} \mathrm{C}$ and fed standard chow diet (ST-1, Velaz, Prague, Czech Republic) were killed by decapitation in diethyl ether anesthesia and interscapular brown fat was dissected and stored in liquid nitrogen. The study protocol was approved by the Animal Care and Use Committee at the Institute of Physiology.

$\boldsymbol{R N A}$ analysis. Total RNA was isolated and analyzed on Northern blots using a full-length cDNA probe for mouse UCP2 and human liver subunit IV of mitochondrial cytochrome oxidase (COX IV), as described previously (11). In addition, a 209-bp fragment corresponding to nucleotides 238

Table 1. Characterization of the cases studied

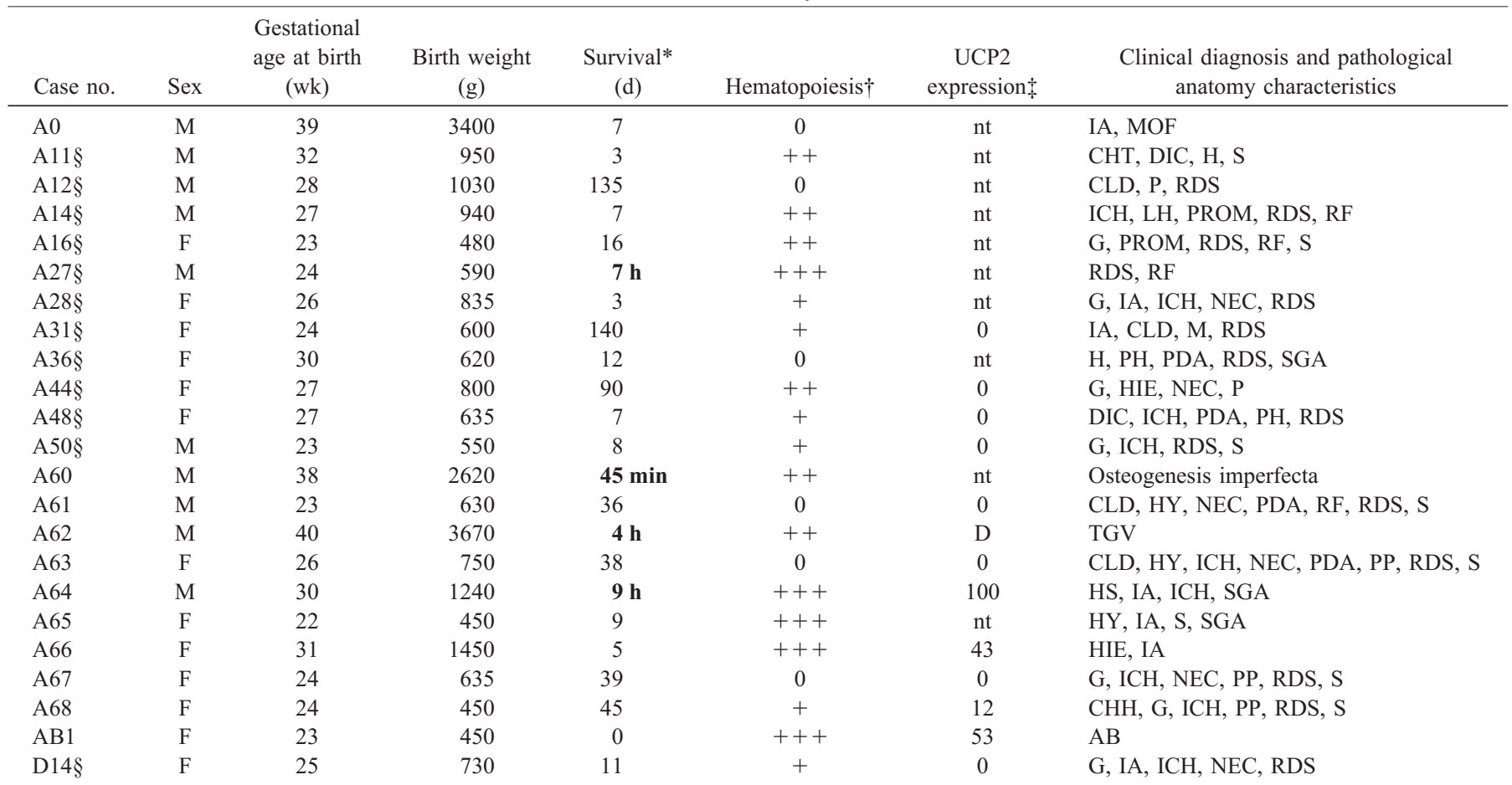

$A B$, abortion elicited for osteochondrodysplasia; $C H H$, cholestatic hepathopathy; $C H T$, chromosomal translocation 45/14q21q; $C L D$, chronic lung disease; $D I C$, disseminated intravascular coagulation; $G$, gemini; $H$, hypotrophy; $H I E$, hypoxic-ischemic encephalopathy; $H S$, hemorrhagic shock; $H Y$, severe hypothermia (body temperature $<31{ }^{\circ} \mathrm{C}$ ) during the early postnatal period; $I A$, intrauterine asphyxia; $I C H$, intracranial hemorrhage; $L H$, lung hypoplasia; $M$, meningitis; $M O F$, multiorgan failure; $N E C$, necrotizing enterocolitis; $O S$, osteochondrodysplasia; $P$, pneumonia; $P P$, peripheral pancytopenia; $P D A$, patent ductus arteriosus; $P H$, pulmonary hemorrhage; $P R O M$, premature rupture of membranes; $R D S$, respiratory distress syndrome; $R F$, respiratory failure; $S$, sepsis; $S G A$, small for gestational age (43); $T G V$, transposition of the great vessels.

* In days, except where indicated otherwise (in bold).

$\dagger$ Hepatic hematopoiesis was scored according to the number of nonparenchymal cells (see "Methods"); $n t$, not tested.

$\ddagger$ Evaluated by Northern blotting and hybridization with a 209-bp fragment of human UCP2 cDNA (arbitrary units; see Fig. 2); $D$, degraded RNA.

$\S$ Cases examined in a previous study (25). 
447 of human UCP2 mRNA was used. It was obtained by digestion with HindIII and PvuII of the human UCP2 cDNA inserted into the EcoRI site of the pTRE plasmid (Clontech, Palo Alto, CA, U.S.A.). The presence of equivalent amounts of ribosomal RNA on the blots was checked by UV shadowing at $256 \mathrm{~nm}$. The DECAprime II Random Priming DNA Labeling Kit (Ambion, Austin, TX, U.S.A.; cat. 1455) was used, and the radioactivity was evaluated by Bioimage Analyzing System (BAS-5000, Fuji, Tokyo, Japan).

Immunoblotting analysis. Crude cell membranes were isolated from tissue homogenates by centrifugation at 100,000 g and analyzed by immunoblotting (26). Proteins separated on $15 \%$ polyacrylamide gels were transferred on PVDF (Immobilon-P, Sigma Chemical Co., St. Louis, MO, U.S.A.; cat. P-2938) membrane by electroblotting. The blots were blocked overnight in PBS containing 0.05\% Tween 20 and 5\% nonfat milk. Incubation with the primary antibodies was performed for $12 \mathrm{~h}$ in the same buffer as above, except that the concentration of the nonfat milk was $1 \%$ and the solution also contained $0.1 \%$ sodium azide. The following primary antibodies were used: (a) whole rabbit serum (1:500; C4/98 serum) against UCP1 isolated (27) from mouse interscapular brown fat; (b) sheep anti-rat UCP1 IgG [1:2000; this was a different batch of the antiserum used in previous studies; see refs. (11, 12). and "Acknowledgments"]; (c) rabbit anti-mouse UCP2 IgG against amino acids $144-157$ of the protein from Calbiochem (San Diego, CA, U.S.A.; cat. 662047; 1:500); and (d) rabbit anti-mouse UCP2 antiserum against a 14-amino acid peptide sequence at the C-terminus of the protein from Alpha Diagnostics Intl. (San Antonio, TX, U.S.A.; cat. UCP22-S; $1: 2,000)$. Blots were washed in PBS containing $0.05 \%$ Tween 20 (five times, $5 \mathrm{~min} /$ wash) and incubation with the secondary antibodies was done in the same buffer for $40 \mathrm{~min}$. Secondary antibodies were goat anti-rabbit IgG coupled to horseradish peroxidase (Bio-Rad, Hercules, CA, U.S.A.; cat. 170-6525; 1:100,000) or donkey anti-sheep/goat IgG coupled to horseradish peroxidase (The Binding Site Limited, Birmingham, U.K.; cat. AP360; 1:100,000). The reaction was visualized by chemiluminescence (ECL+Plus Western Blotting Detection System; kit RPN2132; Amersham, Uppsala, Sweden) and detected by Luminescence Analyzing System (LAS-1000, Fuji, Tokyo, Japan). The protein concentration was measured using the bicinchoninic acid procedure (28) and BSA as standard.

Histologic and immunohistochemical evaluations. Human liver samples were fixed $(3 \mathrm{~h})$ in $3.7 \%$ formaldehyde-PBS, dehydrated, and embedded in paraffin. Sections $(5 \mu \mathrm{m})$ were stained with hematoxylin and eosin (Fig. 1, $A$ and $B$ ), and also with trichrome in parallel (not shown). They were then evaluated by a board-certified pathologist (I.V.). Hematopoiesis in the liver was scored on a four-tier scale $(0,+,++$, or +++$)$, based on the number of nonparenchymal cells. Immunohistochemical labeling (Fig. 1, $\mathrm{C}-H$ ) was performed similarly as before (11). Rabbit anti-mouse UCP1 C4/98 antiserum was used to detect UCP2 (see "Results"). In the single labeling protocol, a 1:1000 dilution of the antiserum was used, and the secondary antibodies (anti-rabbit immunoglobulin conjugated with alkaline phosphatase; 1:100 dilution; Dako, Glostrup, Denmark; cat. D0487) were visualized using BCIP/NBT
(Dako). With the double-labeling method, C4/98 antiserum was used at a 1:500 dilution, and UCP2 was revealed using goat anti-rabbit IgG conjugated to Texas red (Jackson, Baltimore, MD, U.S.A.; cat. 111-076-045; 1:100). Monoclonal mouse anti-human CD68 antiserum (Dako, clone PG-M1; cat. M0876; 1:50) was used as a marker specific for monocytes/ macrophages. Secondary antibodies were horse anti-mouse IgG labeled with fluorescein (Vector Laboratories, Inc., Burlingame, CA, U.S.A.; cat. FI 2000; 1:2000). Fluorescence was visualized using a Leica microscope (model DMRB; Leica Microsystems AG, Wetzlas, Germany) and a CCD video camera (model DXC-930; Sony Corporation, Tokyo, Japan). Negative controls were performed by omitting the first antibody.

In situ hybridization. Tissues were fixed in 3.7\% formaldehyde in PBS, dehydrated, and embedded in paraffin. Sections (5 $\mu \mathrm{m})$ were dewaxed and rehydrated through successive baths of Bioclear (a biodegradable xylene substitute; Microstain, Toulouse, France), ethanol (10\% and 95\%), and PBS containing $0.1 \%$ fresh diethylpyrocarbonate. After equilibration in $5 \times$ $\mathrm{SSC}$, the sections were prehybridized for $1 \mathrm{~h}$ at $42^{\circ} \mathrm{C}$ in a solution containing 50\% formamide, $5 \times \mathrm{SSC}$, and salmon sperm DNA $(250 \mu \mathrm{g} / \mathrm{mL})$. Hybridization was performed overnight at $42^{\circ} \mathrm{C}$ in a solution containing $50 \%$ formamide, $5 \times$ SSC, salmon sperm DNA (40 $\mu \mathrm{g} / \mathrm{mL})$, and antisense UCP2 DIG-labeled RNA probe $(0.5 \mu \mathrm{g} / \mathrm{mL})$. The probe was prepared using the DIG RNA Labeling Kit (SP6/T7; Roche Molecular Biochemicals, Mannheim, Germany) by in vitro transcription from SalI-linearized plasmid containing mouse UCP2 cDNA. Samples were washed in $2 \times \mathrm{SSC}$ for $30 \mathrm{~min}$ at room temperature, treated with RNAase A $(20 \mu \mathrm{g} / \mathrm{mL})$ for $20 \mathrm{~min}$ at $37^{\circ} \mathrm{C}$, and washed in $2 \times \mathrm{SSC}$, and in $0.2 \times \mathrm{SSC}$ (each wash for $30 \mathrm{~min}$, twice, at $50^{\circ} \mathrm{C}$ ). UCP2 transcripts were detected using the DIG and the Block Buffer Set, following the manufacturer's instructions, and visualized using a chromogenic substrate BCIP/NBT (Dako). Sections were counterstained with nuclear red.

\section{RESULTS}

Decline of hepatic hematopoiesis after birth. The highest number of hematopoietic cells $(+++)$ was found in four infants (A27, A64, A65, and A66) who died within 9 d after birth, and two of whom (A27 and A64) died within $9 \mathrm{~h}$ postnatally (Table 1 and Fig. $1, A$ and $B$ ). Very high hematopoiesis was also detected in the liver of the aborted fetus (AB1). Relatively high hematopoiesis $(++)$ was observed in six children (A11, A14, A16, A44, A60, and A62) who died within $16 \mathrm{~d}$ of postnatal life, except for infant A44 (who died at $90 \mathrm{~d}$ postnatally). On the other hand, a negligible hematopoietic activity (0) was observed in six infants (A0, A12, A36, A61, A63, and A67) who survived for at least $7 \mathrm{~d}$ after birth (the case A0), but mostly much longer than $7 \mathrm{~d}$ (Table 1). Other infants (cases A28, A31, A48, A50, A68, and D14) had low but detectable hematopoiesis $(+)$ in the liver and died between 3 and $140 \mathrm{~d}$ after birth.

The results suggest an acceleration of the decline in the number of hematopoietic cells in the liver following birth. In general, no link between the postnatal decline of hematopoiesis 

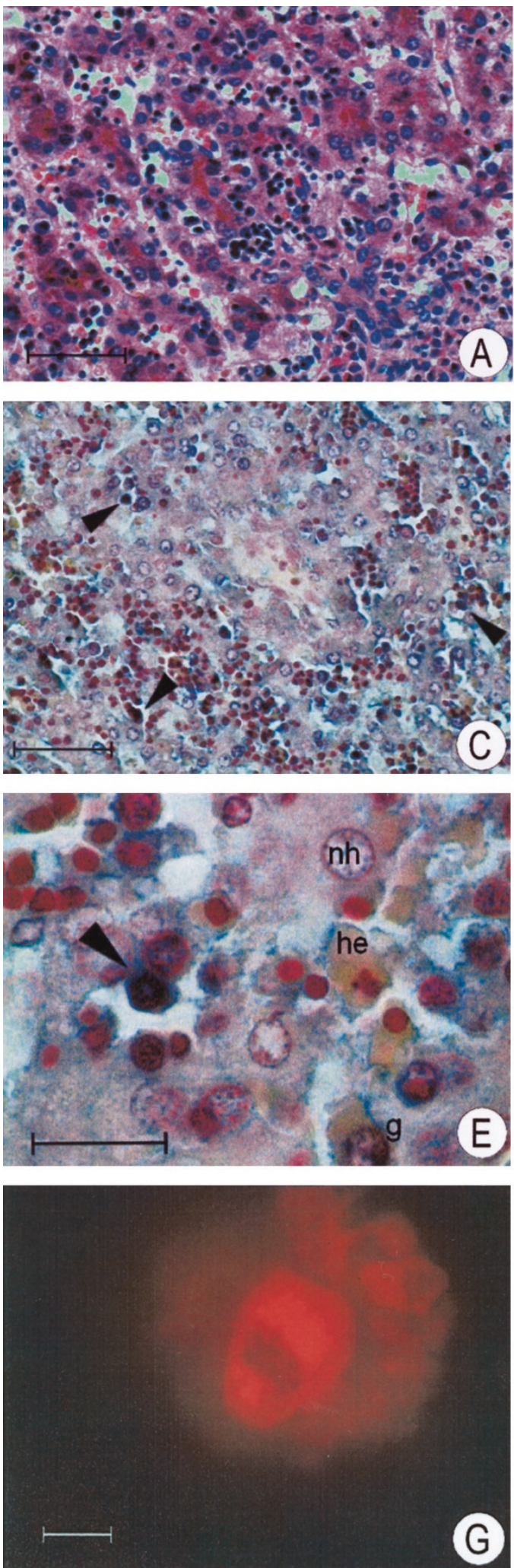
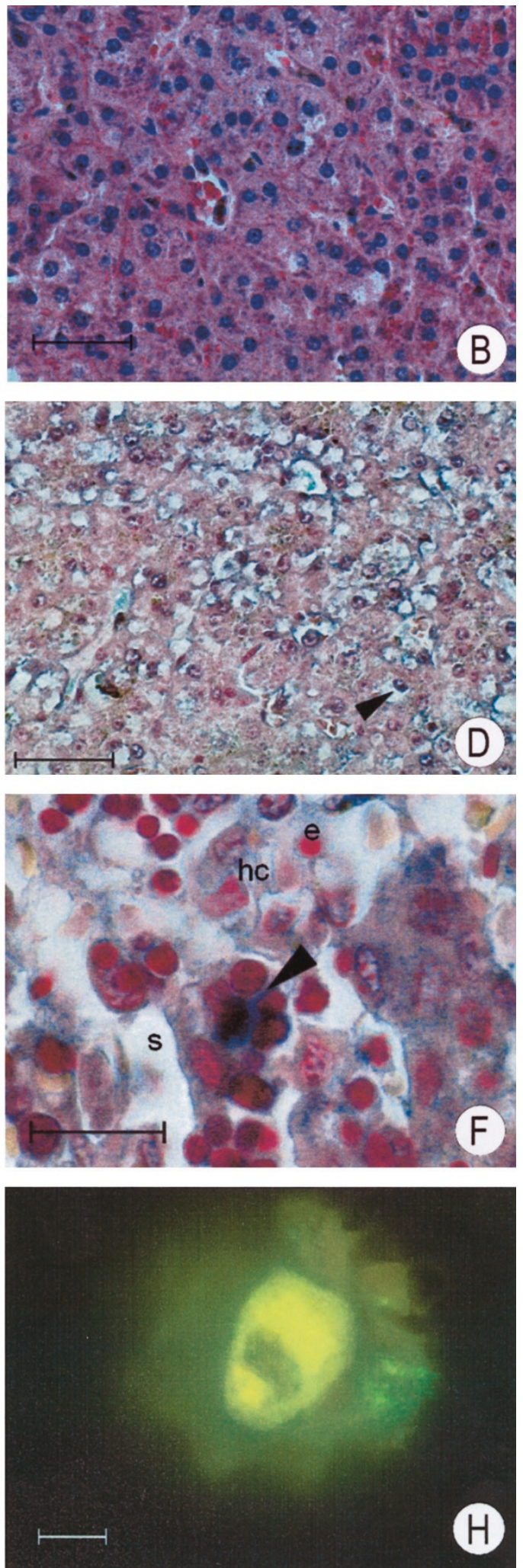

Figure 1. Microphotographs of histologic and immunohistochemical analysis of newborn liver. $A$ and $B$ : Sections stained with hematoxylin and eosin. $C-F$ : Single immunohistochemical detection of UCP2 using anti-mouse UCP1 antiserum. $G$ and $H$ : Double immunohistochemical labeling of UCP2 (Texas red; micrograph $G$ ) and CD68 (fluorescein; micrograph $H$ ). $A, C, E, G$, and $H$ : The newborn A64 who died $9 \mathrm{~h}$ after birth at 30 wk of gestation. $B$ and $D$ : The infant A63 who died $38 \mathrm{~d}$ after birth at 26 wk of gestation. F: the newborn A66 who died $5 \mathrm{~d}$ after birth at 31 wk of gestation (see Table 1 for further details). In panel $A$, there is evidence of considerable hematopoiesis $(+++)$, whereas in panel $B$, no hematopoiesis is seen $(0)$. In panels $C-F$, dark blue precipitates indicate BCIP/NBT deposit in UCP-positive cells (arrows). Counterstain is rouge nuclear. In panel $D$, one UCP-positive cell is seen, but such cells were rare and the section was graded as 0 . In panels $E$ and $F$, the following structures are labeled: Erythroblasts $(e)$, hepatic cord $(h c)$, nucleus in a hepatocyte $(n h)$, hemolyzed erythrocytes (he), granulocyte $(g)$, sinusoid $(s)$, and macrophages (arrow) located in sinusoid (panel $E$ ) or placed centrally in an erythroblastic island (micrograph $F)$. Bar $=60 \mu \mathrm{m}(A-D)$, bar $=20 \mu \mathrm{m}(E$ and $F)$, and bar $=5 \mu \mathrm{m}(G$ and $H)$. 
and the gestational age, the clinical diagnosis, or the pathologic anatomy characteristics could be found (Table 1). The only exception could be prenatal or postnatal hypoxia (Table 1, neonates with intrauterine asphyxia and respiratory distress syndrome, respectively), which was frequently present in the infants with high hematopoiesis.

Decline of UCP2 expression in neonatal liver. To characterize the expression of UCP2 mRNA in human liver, total RNA isolated from 14 out of 23 cases in our cohort (Table 1) was analyzed using Northern blots (Fig. 2). Total RNA was also isolated from mouse interscapular brown fat, which contained UCP2 mRNA $(17,18)$ and was used as a standard for identification of UCP2 transcript in human samples (Fig. 2). In spite of the fact that the liver samples have been collected 2-3 h after death, only one sample (case A62) contained RNA that was highly degraded, as revealed by UV shadowing of the blots. RNA in the other liver samples was more than $70 \%$ intact (not shown, see also below). When hybridized using a full-length cDNA for mouse UCP2, significant levels of UCP2 transcript in the liver were detected (Fig. 2 and Table 1) only in the aborted fetus (case AB1) and in two infants (cases A64 and A66) who died within $5 \mathrm{~d}$ after birth. A marginal expression was detected in one more infant (case A68; not shown). The size of the transcript $(1.7 \mathrm{kbp})$ was similar in both liver and brown fat samples, indicating its identity with UCP2 mRNA. Rehybridization with a 209-bp human UCP2 probe (corresponding to a divergent region of human and mouse UCP2 cDNA sequence) confirmed the results. No reactivity was observed in mouse brown fat, indicating high specificity of the 209-bp probe for the human UCP2 mRNA. Final rehybridization with a cDNA probe for subunit IV of mitochondrial cytochrome oxidase from human liver indicated the presence of the transcript of the subunit in all human liver samples (Fig. 2). The signal was very weak in brown fat, apparently reflecting the differences in the sequence of cytochrome oxidase

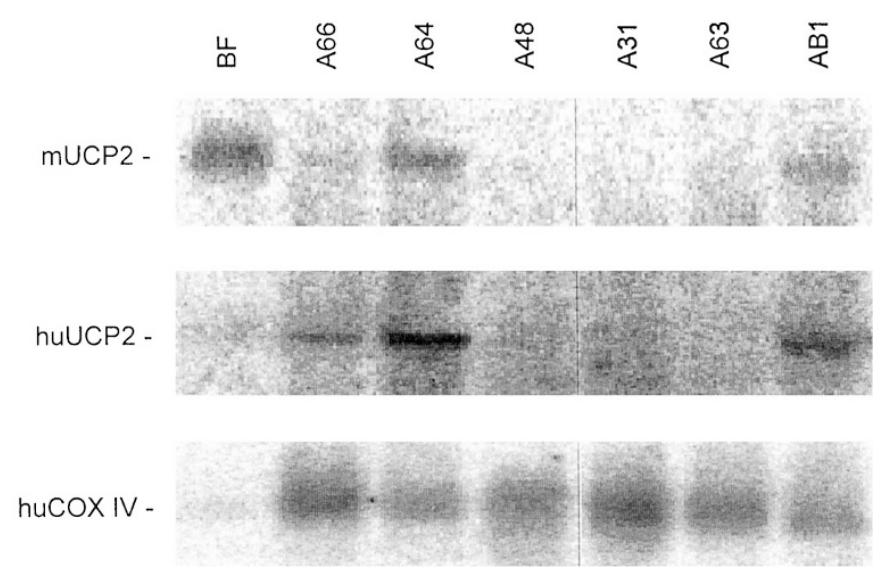

Figure 2. Northern blot analysis of gene expression in human fetal and newborn liver. Total RNA was isolated from the liver of human fetus and newborns (see Table 1) and mouse brown fat $(B F)$. Hybridization was performed using a full-length cDNA probe for mouse UCP2 (mUCP2, 1.7-kbp transcript); the blot was rehybridized using a 209-bp fragment of human UCP2 cDNA (huUCP2, 1.7-kbp transcript) and finally rehybridized using a cDNA probe for human liver subunit IV of mitochondrial cytochrome oxidase (huCOX IV, 0.9-kbp transcript). Two different parts of the same blots are shown. subunit IV between human and mouse (Fig. 2). These results documented that the absence of detectable UCP2 mRNA in the majority of human liver samples did not reflect degradation of RNA. Besides the liver, UCP2 was expressed also in the heart, skeletal muscle, spleen, lung, and adipose tissue. However, the levels of the transcript detected in various organs were always lower compared with that in the liver of the fetus or newborns who died soon after birth (not shown).

Expression of UCP2 in myeloid cells. Further experiments were focused on the immunohistochemical identification of UCP2-producing cells. Because there is almost no convincing published description of antibodies specifically reacting with human UCP2 [see ref (19).], various antibodies were first characterized using immunoblotting: Two types of antibodies against whole UCP1 isolated from brown adipose tissue of rodents and two types of the anti-UCP2 antibodies raised against 14 amino acid peptide sequences from different parts of mouse protein (see "Methods") were compared. Membranous fractions isolated from human liver differing in the level of UCP2 mRNA (cases A63 and A64, with a negligible or high UCP2 transcript level, respectively; see Fig. 2), as well as mitochondria isolated from interscapular brown fat of the mouse, were used (Fig. 3). In brown fat [containing UCP1, $\operatorname{UCP} 2$, and $\operatorname{UCP} 3(17,18,20)]$, all except one of the antibodies recognized the antigen with an apparent molecular mass close to $33 \mathrm{kD}$ (Fig. 3, $A-D$ ). Regarding the similarity in molecular mass and a high sequence homology of all three UCP (19), the
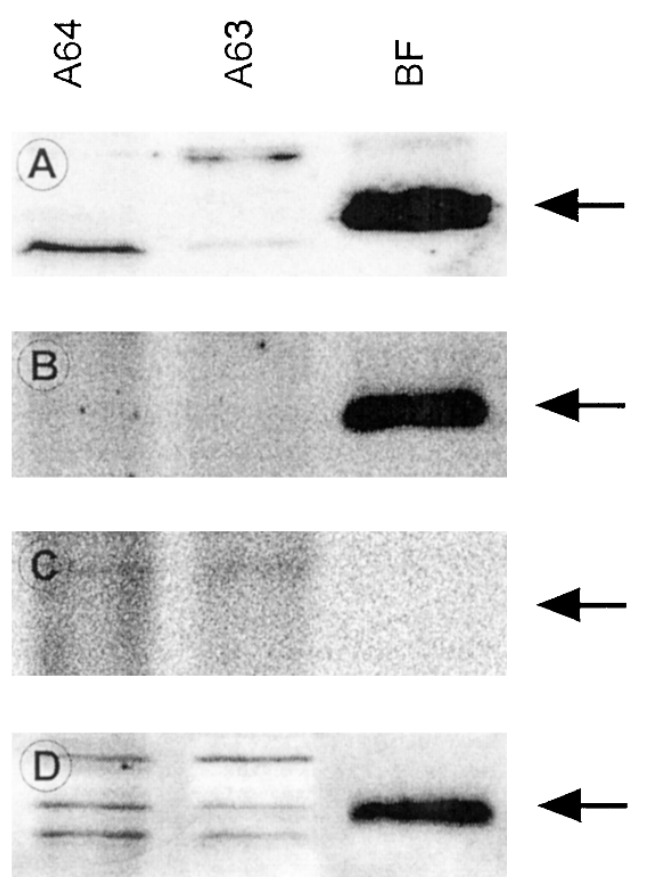

Figure 3. Immunoblotting analysis of gene expression in human newborn liver. Membranous fractions isolated from the liver (30 $\mathrm{gg}$ protein) of the infant with undetectable (case A63) or high (case A64) level of UCP2 transcript, respectively (see Fig. 2), and mouse brown fat (BF;2 $\mu$ g protein) were analyzed using $(A)$ the rabbit anti-mouse UCP1 antiserum; $(B)$ sheep anti-rat UCP1 IgG; $(C)$ rabbit anti-mouse UCP2 IgG against amino acids 144-157 of the protein from Calbiochem (San Diego, CA, U.S.A); and (D) rabbit anti-mouse UCP2 antiserum against a 14 amino acid peptide sequence at the C-terminus of the protein from Alpha Diagnostics (San Antonio, TX, U.S.A.). Arrow, position of the $33-\mathrm{kD}$ antigen (UCP1) in brown fat. 
$33-\mathrm{kD}$ antigen in brown fat could correspond to any of these proteins. In the liver, only the anti-mouse UCP1 antiserum recognized a single band in the $33-\mathrm{kD}$ region (Fig. $3 A$ ), in the infant with high UCP2 mRNA (case A64) and not in the other infant (case A63). In the absence of either UCP1 or UCP3 in the liver $(11,12,29,30)$ the $33-\mathrm{kD}$ antigen recognized by anti-UCP1 antiserum should represent UCP2 $(11,12)$. This antiserum, apparently cross-reacting with human UCP2, also revealed a major band at approximately $15 \mathrm{kD}$ in all the liver samples. However, this band did not correlate with the levels of UCP2 transcript and could represent a nonspecific interaction of the antiserum with proteins loaded in relatively large quantities on the polyacrylamide gel [not shown; see also ref (31).]. The anti-rat UCP1 antiserum reacted with the $33-\mathrm{kD}$ antigen in mouse brown fat (Fig. 3B) and with UCP2 in mouse liver (11, 12); however, it did not cross-react with human UCP2 (Fig. $3 B$ ). One of the antisera raised against the peptide sequences of UCP2 did not show any significant reactivity with the human liver samples in the 33-kD region (Fig. 3C), whereas the other antiserum revealed several faint bands (Fig. 3D).

Based on the above experiments, the anti-mouse UCP1 antiserum cross-reacting with human UCP2 (see above) was selected for the immunohistochemical staining of the human liver samples. The single-labeling experiment revealed strongly UCP-positive cells in nonparenchymal cells in the liver of the newborn who survived for only $9 \mathrm{~h}$ and had intense hepatic hematopoiesis and high UCP2 expression (Table 1, case A64). However, neither erythroid cells nor hepatocytes were stained (Fig. 1, $C$ and $E$ ). Most of the labeled cells had sinusoid localization and showed morphology typical of Kupffer cells. Some monocytes and other myeloid cells (presumably granulocytes) were also labeled, but these cells were stained less than the Kupffer cells (Fig. 1E). In the other neonate with high hematopoietic activity and UCP2 expression in the liver (Table 1, case A66), strongly UCP-positive cells were also detected in the liver parenchyma. These cells were placed centrally in the erythroblastic islands and surrounded by erythroid cells (Fig. 1F). Morphology of these cells and their position in the erythroblastic islands were typical of the Kupffer cells $(8,32)$. Examination of the liver of the infant with negligible hepatic hematopoiesis and undetectable UCP2 expression (Table 1, case A63) revealed very few UCP-positive cells (Fig. 1D). These results, indicating UCP2 expression in the nonparenchymal cells, and not in hepatocytes, were confirmed by the single-labeling analysis with the anti-mouse UCP1 antiserum in all the infants from our cohort (not shown).

Monocyte/macrophage cells can be characterized by expression of specific antigenic markers including cytoplasmic CD68. A double-labeling experiment indicated that antigens recognized by the anti-mouse UCP1 antiserum (Fig. 1G) and by the anti-human CD68 antibody (Fig. $1 H$ ) were located in the same cells. However, not all the UCP-positive cells were stained with the anti-CD68 antibody and vice versa (Fig. $1 H$ ). These experiments supported the view that the majority of the UCP-positive cells were identical with Kupffer cells. To confirm this notion, in situ hybridization experiment was performed (Fig. 4). Analysis of the liver of the neonates with high hematopoietic activity (cases A64 and A66) clearly revealed the presence of UCP2 transcript in cells with the morphology and localization typical of Kupffer cells (Fig. 4, $A$ and $B$; compare with Fig. 1, $E$ and $F$ ).

\section{DISCUSSION}

Results of this study document that the process of birth accelerates the decrease in the content of hematopoietic cells in the liver. The gestational age affects the number of hematopoietic cells in the liver at birth but not the rate of their disappearance from the liver (Table 1). Hepatic hematopoiesis was largely suppressed within $7 \mathrm{~d}$ of postnatal life in a majority of the newborns, in spite of the difference in their gestational age at birth (between 23 and $40 \mathrm{wk}$, see Table 1). A recent study on mice indicated an abrupt postnatal decrease of hematopoietic cells in the liver and suggested that the elevation of blood oxygen tension at birth was the precipitating factor of the decrease (6). This mechanism was probably also responsible for the destruction and steatosis observed postpartum in the mouse liver, as well as for the neonatal granulocytosis (6). Oxygen stress at birth may also contribute to the termination of fetal hepatic hematopoiesis in humans, whereas intrauterine or postnatal hypoxia seem to promote liver hematopoiesis (Table 1). However, no association between liver steatosis and early postnatal death of human newborns was detected, whereas
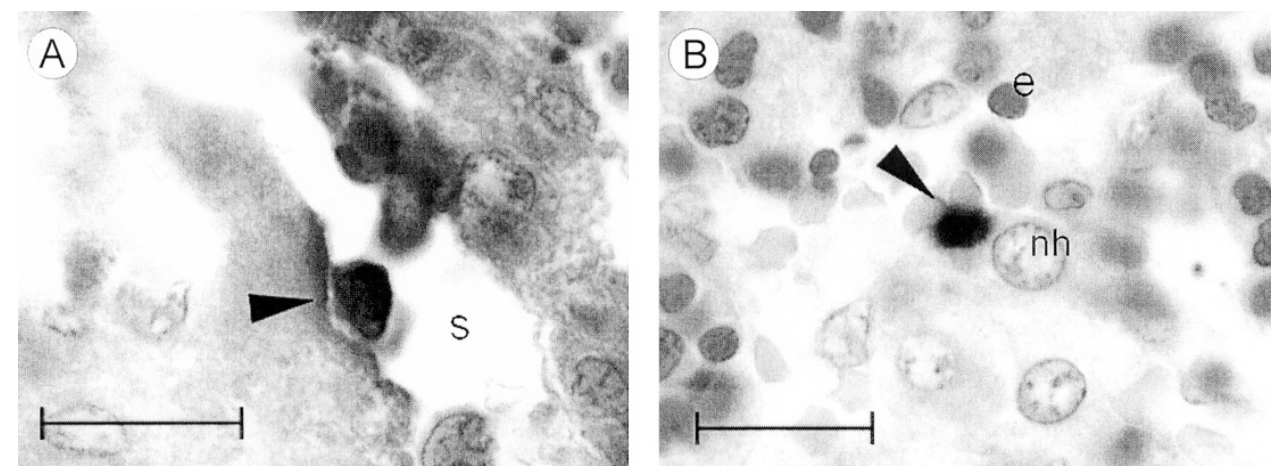

Figure 4. Microphotographs of $i$ situ hybridization analysis of UCP2 transcript in newborn liver. The mRNA UCP2 was detected as described in "Methods" and visualized using BCIP/NBT. In panel $A$, the newborn A64, in panel $B$, the newborn A66 (for details, see Fig. 1 and Table 1). The following structures are labeled: UCP2 transcript-positive cells (black arrow), sinusoid $(s)$, nucleolus in a hepatocyte $(n h)$, and erythroblast $(e)$. Bar $=20 \mu \mathrm{m}$. 
steatosis was observed in the majority of infants with sepsis (not shown).

Concerning the UCP2 expression, high levels of UCP2 transcript were only detected in two neonates (Table 1, cases A64 and A66) who died within $5 \mathrm{~d}$ after birth, and in the fetus (Table 1, case AB1). In all these cases, hepatic hematopoiesis was also very intense $(+++)$. On the other hand, no infant with undetectable UCP2 transcript by Northern blot analysis survived less than $7 \mathrm{~d}$ (Table 1). These results indicate that UCP2 expression in human liver ceases soon after birth, similarly as in rodents. The correlation between the number of hematopoietic cells and the level of UCP2 transcript strongly indicated that nonparenchymal cells represented the major site of UCP2 expression in the fetal and neonatal liver. Immunohistochemical analysis and in situ hybridization documented UCP2 expression in monocyte/macrophage cells, similarly as found in mice and rats (11). Macrophages in human liver showed a much higher UCP2 content compared with the other cell types, but the anti-UCP1 serum also reacted significantly with some other myeloid cells. Recent studies indicated that UCP2 might be induced in hepatocytes in adult rodents under various pathologic situations (see "Introduction"). However, no UCP-positive hepatocytes were observed in any infant (or fetus) included in our experimental cohort, in spite of sepsis and other pathologies (Table 1). Also important, the levels of UCP2 transcript in the liver correlated best with the length of postnatal life (and the activity of hepatic hematopoiesis) and not with the clinical diagnosis or the pathologic anatomy characteristics. Therefore, UCP2 seems to be absent in hepatocytes of human fetuses and critically ill neonates.

The liver appeared to be the major site of UCP2 expression in the fetus and the newborn, both in rodents (11) and in humans (this study) and Kupffer cells, representing (33) the largest population of the body's tissue macrophages $(80 \%$ $90 \%$ ), are the main source of UCP2 in the liver. The expression of UCP2 in these cells must be very high, because Kupffer cells represent less than $1 \%$ of nonparenchymal cells in the liver following the 8th week of gestation (8). Whether the postnatal decline of UCP2 expression only reflects the decrease in the number of hematopoietic cells expressing UCP2 or the differential expression in cells before and after birth is not clear (11). This question is related to the putative function of UCP2.

In nonparenchymal (presumably in Kupffer) cells, but not in hepatocytes isolated from rat liver, UCP2 was shown to decrease mitochondrial ROS production (21). A special subpopulation (34) of macrophages supports erythropoiesis in fetal liver (34), and their concomitant activation may increase ROS production (2). UCP2 may be induced in Kupffer cells activated during erythropoiesis and participate in the self-defense of these cells against oxidative stress. It has also been shown that tumor necrosis factor $\alpha$ could increase ROS production and induce expression of UCP2 in regenerating rat liver. However, the cellular distribution of UCP2 in these experiments has not been assessed (35). Some studies indicate transcriptional control of UCP2 expression by PPAR $\gamma$ in adipocytes (36-38). PPAR $\gamma$, the target for thiazolidinediones used as insulin sensitizers in diabetic patients (39), also promotes monocyte/macrophage differentiation (40) and inhibits macro- phage activation (41). Whether PPAR $\gamma$ stimulates transcription of UCP2 gene in monocytes/macrophages remains to be elucidated. Our previous studies documented phagocytotic activity of preadipocytes and UCP2 expression in these cells (42). It was shown very recently that mice with genetically disrupted UCP2 gene were resistant against infection by Toxoplasma gondii and their macrophages showed higher functional activities, compared with control animals (44). Moreover, high UCP2 content was demonstrated in spleen using reliable antibodies $(44,45)$. Therefore, it is apparent that UCP2 may have a role common to cells engaged in phagocytosis and immunity.

In summary, the present results indicate the rapid postnatal decline of hematopoiesis in human liver, associated with the diminution of mitochondrial UCP2 expression. They document a specific expression of UCP2 in myeloid cells, particularly the Kupffer cells, and suggest that UCP2 is absent from hepatocytes of human neonates.

Acknowledgments. The authors thank Dr. D. Ricquier (CNRS/CEREMOD, Meudon, France) for sheep anti-rat UCP1 IgG; Dr. B.B. Lowell (Harvard Medical School, Boston, MA, U.S.A.) for human and mouse UCP2 cDNAs; Dr. A. ̈̈edivá (Charles University, Prague, Czech Republic), Prof. A. Kotyk and Dr. J. Houštěk (Institute of Physiology, Academy of Sciences, Prague, Czech Republic), and S. Sustková for critical reading of the manuscript. The technical assistance of $P$. Guillou is greatfully acknowledged.

\section{REFERENCES}

1. Hann IM, Bodger MP, Hoffbrand AV 1983 Development of pluripotent hematopoietic progenitor cells in the human fetus. Blood 62:118-123

2. Segel GB, Oski FA 1991 Hematology of the newborn. In: Williams WJ, Beutler E, Erslev AJ, Lichtman MA (eds) Hematology. McGraw-Hill, New York, pp 100-111

3. Migliaccio G, Migliaccio AR, Petti S, Mavilio F, Russo G, Lazzaro D, Testa U, Marinucci M, Peschle C 1986 Human embryonic hemopoiesis. J Clin Invest 78:51-60

4. Lansdorp PM 2000 Developmental changes in the function of hematopoietic stem cells. Exp Hematol 23:187-191

5. Crosbie OM, Reynolds M, McEntee G, Traynor O, Hegarty JE, O'Farrelly C 1998 In vitro evidence for the presence of hematopoietic stem cells in the adult human liver. Hepatology 29:1193-1198

6. Kawamura M, Toyabe S, Moroda T, Iiai T, Takahashi-Iwanaga H, Fukada M, Watanabe H, Sekikawa H, Seki S, Abo T 1997 Neonatal granulocytosis is a postpartum event which is seen in the liver as well as in the blood. Hepatology 26:1567-1572

7. Wood WG 1976 Haemoglobin synthesis during human fetal development. Br Med Bull 32:282-287

8. Kelemen E, Calvo W, Fliender TM 1979 Atlas of Human Hemopoietic Development. Springer Verlag, Berlin, pp 1-267

9. Jordan CT, Zant GV 1998 Recent progress in identifying genes regulating hematopoietic stem cell function and fate. Curr Opin Cell Biol 10:716-720

10. Haan G, Zant GV 1997 Intrinsic and extrinsic control of hemopoietic stem cell numbers: mapping of a stem cell gene J Exp Med 186:529-536

11. Hodný Z, Kolárová P, Rossmeisl M, Horáková M, Nibbelink M, Pénicaud L, Casteilla L, Kopecký J 1998 High expression of uncoupling protein 2 in foetal liver. FEBS Lett 425:185-190

12. Larrouy D, Laharrague P, Carrera G, Viguerie-Bascands N, Levi-Meyrueis C, Fleury C, Pecqueur C, Nibbelink M, André M, Casteilla L, Ricquier D 1997 Kupffer cells are a dominant site of uncoupling protein 2 expression in rat liver. Biochem Biophys Res Commun 235:760-764

13. Cortez-Pinto H, Yang SQ, Lin HZ, Costa S, Hwang CS, Lane MD, Bagby G, Diehl AM 1998 Bacterial lipopolysaccharide induces uncoupling protein-2 expression in hepatocytes by a tumor necrosis factor-alpha-dependent mechanism. Biochem Biophys Res Commun 251:313-319

14. Chavin KD, Yang S, Lin HZ, Chatham J, Chacko VP, Hoek JB, Walajtys-Rode E, Rashid A, Chen CH, Huang CC, Wu TC, Lane MD, Diehl AM 1999 Obesity induces expression of uncoupling protein-2 in hepatocytes and promotes liver ATP depletion. J Biol Chem 274:5692-5700

15. Rashid A, Wu TC, Huang CC, Chen CH, Lin HZ, Yang SQ, Lee FYJ, Diehl AM 1999 Mitochondrial proteins that regulate apoptosis and necrosis are induced in mouse fatty liver. Hepatology 29:1131-1138 
16. Carretero MV, Torres L, Latasa MU, Garcia-Trevijano ER, Prieto J, Mato JM, Avila MA 1998 Transformed but not normal hepatocytes express UCP2. FEBS Lett 439:55-58

17. Gimeno RE, Dembski M, Weng X, Deng N, Shyjan AW, Gimeno CJ, Iris F, Ellis SJ, Woolf EA, Tartaglia LA 1997 Cloning and characterization of an uncoupling protein homologue. Diabetes 46:900-906

18. Fleury C, Neverova M, Collins S, Raimbault S, Champigny O, Levi-Meyrueis C, Bouillaud F, Seldin MF, Surwit RS, Ricquier D, Warden CH 1997 Uncoupling protein-2: a novel gene linked to obesity and hyperinsulinemia. Nat Genet 15:269272

19. Ricquier D, Bouillaud F 2000 The uncoupling protein homologues: UCP1, UCP2, UCP3, StUCP and AtUCP. Biochem J 345:161-179

20. Vidal-Puig A, Solanes G, Grujic D, Flier JS, Lowell BB 1997 UCP3: an uncoupling homologue expressed preferentially and abundantly in skeletal muscle and brown adipose tissue. Biochem Biophys Res Commun 235:79-82

21. Nègre-Salvayre A, Hirtz C, Carrera G, Cazenave R, Troly M, Salvayre R, Pénicaud L, Casteilla L 1997 A role for uncoupling protein-2 as a regulator of mitochondrial hydrogen peroxide generation. FASEB J 11:809-816

22. Jaburek M, Varecha M, Gimeno RE, Dembski M, Jezek P, Zhang M, Burn P, Tartaglia LA, Garlid KD 1999 Transport function and regulation of mitochondrial uncoupling proteins 2 and 3. J Biol Chem 274:26003-26007

23. Cadenas S, Buckingham JA, Samec S, Seydoux J, Din N, Dulloo AG, Brand MD 1999 UCP2 and UCP3 rise in starved rat skeletal muscle but mitochondrial proton conductance is unchanged. FEBS Lett 462:257-260

24. Bienengraeber M, Echtay KS, Klingenberg M $1998 \mathrm{H}^{+}$transport by uncoupling protein (UCP-1) is dependent on a histidine pair, absent in UCP-2 and UCP-3. Biochemistry 37:3-8

25. Pavelka S, Kopecký P, Bendlová B, Štolba P, Vítková I, Vobruba V, Plavka R, Houštěk J, Kopecký J 1997 Tissue metabolism and plasma levels of thyroid hormones in critically ill very premature infants. Pediatr Res 42:812-818

26. Kopecký J, Rossmeisl M, Hodný Z, Syrový I, Horáková M, Kolárová P 1996 Reduction of dietary obesity in the aP2-Ucp transgenic mice: mechanism and adipose tissue morphology. Am J Physiol Endocrinol Metab 270:E776-E786

27. Lin CS, Klingenberg M 1982 Characterization of the isolated purine nucleotide binding protein from brown fat mitochondria. Biochemistry 21:2950-2956

28. Smith PK, Krohn RI, Hermanson GT, Mallia AK, Gartner FH, Provenzano MD, Fujimoto EK, Goekke NM, Olson BJ, Klenk BC 1985 Measurement of protein using bicinchoninic acid. Anal Biochem 150:76-85

29. Boss O, Samec S, Paoloni-Giacobino A, Rossier C, Dulloo A, Seydoux J, Muzzin P, Giacobino JP 1997 Uncoupling protein-3: a new member of the mitochondrial carrier family with tissue-specific expression. FEBS Lett 408:39-42

30. Gong DW, He Y, Karas M, Reitman M 1997 Uncoupling protein-3 is a mediator of thermogenesis regulated by thyroid hormone, beta3-adrenergic agonists, and leptin. J Biol Chem 272:24129-24131

31. Horvath TL, Warden CH, Hajos M, Lombardi A, Goglia F, Diano S 1999 Brain uncoupling protein 2: uncoupled neuronal mitochondria predict thermal synapses in homeostatic centers. J Neurosci 19:10417-10427
32. Naito M 2000 Macrophage heterogeneity in development and differentiation. Arch Histol Cytol 56:331-351

33. Immenschuh S, Tan M, Ramadori G 1999 Nitric oxide mediates the lipopolysaccharide dependent upregulation of the heme oxygenase- 1 gene expression in cultured rat Kupffer cells. J Hepatol 30:61-69

34. Sasaki K, Iwatsuki H, Suda M, Itano C 1993 Scavenger macrophages and central macrophages of erythroblastic islands in liver hemopoiesis of the fetal and early postnatal mouse: a semithin light- and electron-microscopic study. Acta Anat (Basel) $147: 75-82$

35. Lee FYJ, Li Y, Zhu H, Yang SQ, Lin HZ, Trush M, Diehl AM 1999 Tumor necrosis factor increases mitochondrial oxidant production and induces expression of uncoupling protein-2 in the regenerating rat liver. Hepatology 29:677-687

36. Aubert J, Champigny O, Saint-Marc P, Negrel R, Collins S, Ricquier D, Ailhaud G 1997 Up-regulation of UCP-2 gene expression by PPAR agonists in preadipose and adipose cells. Biochem Biophys Res Commun 238:606-611

37. Strobel A, Siquier K, Zilberfarb V, Strosber AD, Issad T 1999 Effect of thiazolidinediones on expression of UCP2 and adipocyte markers in human PAZ6 adipocytes. Diabetologia 42:527-533

38. Kelly LJ, Vicario PP, Thompson GM, Candelore MR, Doebber TW, Ventre J, Wu SM, Meurer R, Forrest MJ, Conner MW, Cascieri MA, Moller DE 1998 Peroxisome proliferator-activated receptors gamma and alpha mediate in vivo regulation of uncoupling protein (UCP-1, UCP-2, UCP-3) gene expression. Endocrinology 139:4920-4927

39. Lowell BB 1999 PPARgamma: an essential regulator of adipogenesis and modulator of fat cell function. Cell 99:239-242

40. Tontonoz P, Nagy L, Alvarez JG, Thomazy VA, Evans RM 1998 PPARgamma promotes monocyte/macrophage differentiation and uptake of oxidized LDL. Cell 93:241-252

41. Ricote M, Li AC, Willson TM, Kelly CJ, Glass CK 1998 The peroxisome proliferator-activated receptor-gamma is a negative regulator of macrophage activation. Nature 391:79-82

42. Cousin B, Munoz O, André M, Fontanilles AM, Dani C, Cousin JL, Laharrague P, Casteilla L, Pénicaud L 1999 A role for preadipocytes as macrophage-like cells. FASEB J 13:305-312

43. Lubchenco LO, Hansman C, Dressler N, Boyd E 1963 Intrauterine growth as estimated from life-born birth weight data at 24-32 weeks of gestation. Pediatrics 32:793-800

44. Arsenijevic D, Onuma H, Pecqueur C, Raimbault S, Manning BS, Miroux B, Couplan E, Alves Guerra MC, Goubern M, Surwit R, Boillaud F, Richard D, Collins S, Ricquier D 2000 Disruption of the uncoupling protein-2 gene in mice reveals a role in immunity and reactive oxygen species production. Nat Genet 26:435-439

45. Pecqueur C, Alves-Guerra MC, Gelly C, Levi-Meyrueis C, Couplan E, Collins S, Ricquier D, Bouillaud F, Miroux B 2001 Uncoupling protein 2: in vivo distribution, induction upon oxidative stress and evidence for translational regulation. J Biol Chem (in press) 